\title{
Same same but different
}

\author{
I distriktsturnus sov Helen Brandstorp med yttertøyet på - for sikkerhets skyld. \\ Nå forsker hun på erfaringene sine som leder for utallige akuttmedisinske kurs \\ i den nordnorske førstelinjen.
}

Klikk klakk klikk klakk. Det er kvelden før intervjuet formelt skal finne sted. Scenen er festmiddag med kolleger fra de tre nordligste fylkene. Stemningen er stigende mellom reinsdyrstek og multekrem, vitsene som akkurat er avlevert om Tana-breddens viderverdige univers hylende morsomme. Helen Brandstorp har reist seg og forlater bordsetet, rolig, men med ettertrykk.

- Er det nødvendig å være så demonstrativt korrekt? I dagens frigjorte multikulturelle univers er det vel rom for en ganske godartet vits med samer i hovedrollen? Du er jo ikke same selv engang...

- Nettopp derfor. Jeg vil svare med en opplevelse som gjorde at jeg forsto mer. For noen år siden skulle mannen min, som er same, og jeg i bryllup sørpå. Han vegret seg da jeg ba ham ta på seg sitt kulturelle stasplagg - kofte. Etter hvert som festen tok av, skjønte jeg smertelig godt hvorfor. De «artige» kommentarene - skvettlapp, grytelapp, hundrelapp var vi ikke foreberedt på. Etterpå var han resignert og lei seg. For meg er det vesensforskjellig om man ler på sin egen eller andres bekostning. Å fortelle samevitser i en forsamling der du ikke vet hva eller hvem du tråkker på, synes jeg ikke er greit.

Det hører med til historien at den nevnte representanten fra Tana-bredden og Helen Brandstorp er på god fot $\mathrm{i}$ andre sammenhenger og har hatt denne uenigheten som en slags langsgående føljetong gjennom flere år og mange fester. Ved én anledning skal han ha slått på glasset og innledet med: «Nå, Helen, kan du gå på toalettet og bli der litt.»

\section{Å våke i verdens natt}

Helen Brandstorp fremstår som et engasjert menneske, en som vil. Mye, godt, riktig, på vegne av. I 2005 ble hun hedret med Løvetannprisen, norsk allmennmedisins egen utmerkelse. Hun opptrer på mange arenaer med synlig pågangsmot og stor formidlingsevne. Blant kolleger er hun best kjent for sitt nybrottsarbeid innen akuttmedisin i den medisinske førstelinjen. En tilfeldig sakset overskrift av mange mulige ser slik ut: «I hver tiende kommune varsler ikke AMK-sentralene lege ved akutte, kritiske nødmeldinger. - Dette er alvorlig; legene er for sløve med å bruke helseradioen, hevder
Helen Brandstorp ved Nasjonalt senter for distriktsmedisin» (1). I debatten om kjønn, makt og skjulte agendaer som fulgte etter årsmøtene i Allmennlegeforeningen og Norsk forening for allmennmedisin i vår, var hun blant dem som markerte seg kritisk feministisk - for øvrig i åpen uenighet med intervjueren.

- Du skrev, ikke uten selvironi, til meg i forkant av denne samtalen at du er interessert i «litt teologi og sosiologi og politikk og sånn» og «nesten alle kulturuttrykk». Bredden, engasjementet og nysgjerrigheten er lett å få øye på. Men hvor er tyngdepunktet ditt?

- Jeg har alltid gjort bevisste valg, slitsomt bevisste egentlig. Samtidig opplever jeg meg i besittelse av en emosjonell kraft som både ytrer seg som spontanitet, men også gir dybde til tvilen. Jeg er ikke ubevisst om tro og tvil. Det er en salme som starter med «noen må våke i verdens natt». Enkelt sagt tenker jeg at mine ressurser og muligheter er gitt meg for intet og at jeg skal gi tilbake etter beste evne.

Hun bruker det for meg fremmede uttrykket «for intet» som om det var dagligtale. Jeg noterer det i margen, tror jeg vet hvor jeg skal lete. Litt beskjemmet går jeg likevel til Google og ikke Bibelen. Der står det, i Evangeliet etter Matteus 10,8: «Helbred syke, vekk opp døde, gjør spedalske rene, driv ut onde ånder. For intet har dere fått det, for intet skal dere gi det.»

- I studietiden fant jeg frem til troen. Jeg tenker om det som en religiøs reaksjon på oppveksten i et tidstypisk sekulært miljø med lite næring til min undring og leting etter svar på de store spørsmålene. Kall det gjerne et opprør. For dem hjemme var det nok først rart, det var litt sånn lavmælt kringkasting dem imellom om at «Helen er blitt religiøs».

- Det sies at du har et høyt forbruk av prester?

- Det er klart det vakte en viss oppsikt at jeg ankom Tana som kjæreste til den påtroppende presten og i stedet giftet meg med stedets daværende sogneprest. For noen førte det vel til at jeg måtte bevise litt ekstra at jeg var til å stole på, for andre ble det trolig en tankevekker. Prestefruer er ikke bedre enn andre.

\section{Improvisasjonskompetanse}

Som student skaffet hun seg utvekslingsopphold i Lübeck, London og Burkina Faso. Etter preklinikken stakk hun av til de sveitsiske alper for å stå på ski og jobbe på hotell, etterfulgt av et halvt år i Paris for å lære språk. Så havnet hun altså som kommunelege i Tana og medlem av Samisk legeforening. I fem år var hun en aktivt skrivende medredaktør i det allmenn- og samfunnsmedisinske tidsskriftet Utposten, en dugnadsjobb som verken gir berømmelse eller fortjeneste. Hun har ikke tall på alle de akuttmedisinske kursene og treningssamlingene hun har holdt for helsepersonell ute i kommunene. For tiden kurser hun turnusleger i distrikt i Troms og Finnmark i tillegg til forskerjobben ved Nasjonalt senter for distriktsmedisin ved Universitetet i Tromsø, der hun også fungerer som webredaktør.

Helen Brandstorps mann er generalsekretær i Samisk kirkeråd og en sentral skikkelse innen samisk kirkeliv og teologi. Han er oppvokst i Østfold, han også, viser det seg, i Rygge - nabokommunen til Moss. The boy next door. Verden er rar. Nå pendler han til Oslo på ubestemt tid. Selv tenker Helen Brandstorp å bli boende i Tromsø. Eller Afrika. Eller... Hennes tilhørighet er ikke stedbundet. Hun bruker mange metaforer når hun beskriver sin posisjon i verden, gjerne ispedd samiske begreper og myter.

- Tradisjonelt er nordmenn definert av hjemmet, slekten og stedet. Du er ikke lett å plassere i det aksesystemet.

- Jeg er nok mer opptatt av tilblivelse, av å ta imot livet uten forbehold. Det betyr også å la seg dytte hit og dit i møter med mennesker og hendelser underveis. Nei, jeg er ikke redd for å miste fotfestet. For meg er det tvert imot slik at jeg har måttet arbeide for å gi slipp på kontrollen og ha tillit til det som måtte komme. Siden jeg ikke har barn, har jeg dessuten større handlingsrom for å utvikle det jeg kaller improvisasjonskompetanse.

\section{Best i test}

Da tvillingsøstrene Brandstorp var 13 år, troppet de opp i Moss sparebank for å investere overskuddet fra en svært nøktern ukelønn i obligasjoner. Én hver. Bedre 


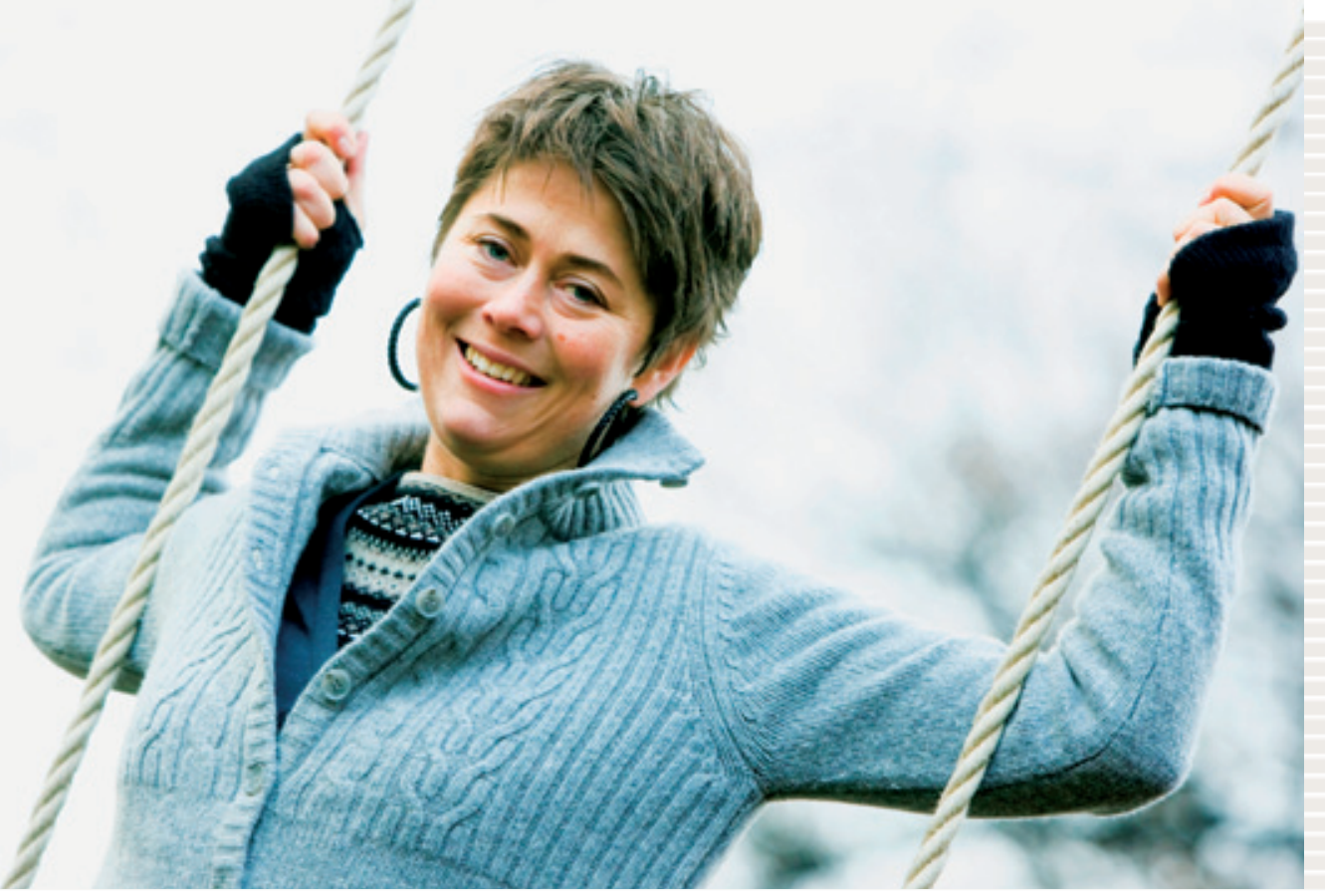

føre var enn etter snar. Som turnuslege i distrikt sov hun for sikkerhets skyld fullt påkledd og rykket ut til alt som rørte seg.

- Jeg var så redd at jeg ikke greide å prioritere. Fikk høy puls uansett. Alltid beredt, eksempelvis for hastebesøk til vaginitt på en søndag.

Nå forsker Helen Brandstorp på akuttberedskap i førstelinjen. Hun skriver på en doktorgrad basert på mange års erfaring som pådriver og instruktør i et prosjektet som ble initiert av ildsjeler i en stiftelse med det velklingende akronymet BEST BEdre og Systematisk Traumebehandling. Selve konseptet er utviklet i og for sykehus (2), men Helen Brandstorp og hennes medarbeidere i nord har tilrettelagt og utviklet et opplegg basert på de samme ideene for akuttmedisinske team i førstelinjen (3).

- Som kommunelege i Tana kom jeg til et velfungerende legekontor som ga meg oppgaver jeg vokste på. Jeg fikk ansvar for sykestuen, akuttmedisinen og legevakten og oppdaget at jeg trivdes som leder av et operativt team.

- Du påpeker at allmennlegene må kjenne sin rolle i den akuttmedisinske kjeden. I dag ser vi tendensen til at ambulansepersonell og AMK-sentraler tar seg av blålysoppdragene og at mange allmennleger trekker et lettelsens sukk når de hører sirenene ule forbi kontoret på vei til sykehuset.

- Det er ikke er bra for pasientene og ikke for dem som jobber i helsevesenet heller dersom allmennlegene ikke er oppdatert på den delen av faget som handler om å redde liv i akuttsituasjoner. Det går på troverdigheten løs. I distriktene blir det spesielt tydelig hvis legen ikke kan sine ting. Folk kan jo bytte lege, men du skal møte pasientene og de pårørende - eventuelt etterlatte - på butikken i ettertid.

- Mange vil innvende at allmennleger har fint lite å bidra med når det virkelig haster?

- Det er feil. Mange allmennleger er ekstremt gode til å improvisere, vant som de er med å ta det som ramler inn døren i en åpen, uselektert praksis. Ambulansepersonell er gode til å hoppe på når alarmen går, men er mye mer prosedyrestyrt og opplært til alltid å katastrofetenke. Fordi akuttmedisinen er like mangfoldig som andre deler av faget, er allmennlegens vurderinger nyttige. Innleggelser unngås, angsten roes, tiltakene blir mindre dramatiske. Et tverrfaglig samarbeid, slik jeg har erfart det i egen praksis, fører til at pasientene får hjelp fra et team med komplementær kompetanse. De effektive prosedyrene er viktige, ikke minst på grunn av tidsbruk. Men også akuttmedisin er skreddersøm og må til sjuende og sist være pasientsentrert, ikke prosedyresentrert.

- Du er blitt berømt for de praksisnære øvingssamlingene dine ute i kommunene. Er det ikke et paradoks at du, som altså jobber for å slippe kontrollen, er blitt en slags reisende i verstefallstenkning?

- Jeg er nok med mitt lett stimulerbare nervesystem ganske klar for «worst case». Men ved å være trygg på egen kompetanse, også i møte med det man frykter mest, er mulighetene større for improvisasjon. Når det gjelder akuttmedisin på kommunenivå, synes jeg det legges for stor vekt på planlegging og for lite på konkret trening. Man kan planlegge seg bort fra deltakelse, det er min påstand. Jeg lar deltakerne øve i sin egen kontekst - på jobb - med sitt eget utstyr og egne kolleger - leger, ambulansepersonell, sykepleiere og legesekretærer og på noen småsteder også annet helsepersonell. Teamet settes sammen tilfeldig, slik det er på vakt. Først øver vi på en situasjon, så reflekterer vi over felles erfaring. «Pasienten» er en selvsagt og interessant deltaker. Vi snakker først om opplevelsen, så om det som gikk godt og dernest om det som kunne vært annerledes. Alles stemme teller like mye. Så bestemmer teamet hvilke forbedringer de vil øve på før vi kjører ny runde med etterfølgende reflek-

\section{Helen Brandstorp}

Født 20. juni 1970 i Moss

- Cand.med. Universitetet i Bergen 1996

- Kommunelege 2 i Tana og Nesseby 1998-2006

- Medredaktør Utposten 2003-08

- Prosjektleder akuttmedisinsk opplæring i førstelinjen fra 2005

- Overlege ved akuttmedisinsk avdeling, Universitetssykehuset NordNorge, 2007-08

- Forsker ved Nasjonalt senter for distriktsmedisin, Universitetet i Tromsø, fra 2007

Foto Berit Roald/SCANPIX

sjon. Metoden er inspirert av Paulo Freires frigjøringspedagogikk.

- Når du nå ser på erfaringene dine samlet, som forsker, hva er de viktigste funnene foreløpig?

- Etter å ha trent noe sånt som 150 ulike team vet jeg jo at kommunikasjon, ledelse og rollefordeling engasjerer både etter øvinger og virkelige hendelser. Selv i opphetede situasjoner er det ikke overraskende at inkludering, tillit og respekt for hverandres styrke og svakheter er det som gir best uttelling.

\section{Multiverset}

Vi har snakket lenge og skålt begeistret for samforståelse, uenighet og mangfold over luksusvarianten av take-away-sushi og utsøkt vin. Helen Brandstorp liker kanskje å ta livet som det kommer, men hun har ikke tatt noen sjanser med måltidet hun serverer. Dessuten har hun det usedvanlig ryddig i en leilighet preget av nøye gjennomtenkt og lavmælt estetikk med mening. Unntaket er et stort, litt banalt bilde som minner mistenkelig om Ikea, sentralt plassert over spisebordet. Noen kvister mot en lys himmel. Det er vel et eller annet samisk, tenker jeg, og skammer meg over min manglende følsomhet i møte med urfolkets uttrykk.

- Lurer du på det bildet? Det er fra Ikea. Plassen er egentlig reservert for et stort relieff som vi har bestilt fra en samisk kunstner. Der skal det stå: «Det gode skal du hugge i fjell. Det onde skal du skrive i sne.»

\section{Elisabeth Swensen}

elswense@online.no

Tidsskriftet

\section{Litteratur}

Varsler ikke lege ved akutt alarm. Dagens Medisin 30.1.2009.

2. www. bestnet.no (22.12.2009).

3. Utsi R, Brandstorp $H$, Johansen $K$ et al. Tverrfaglig akuttmedisinsk teamtrening i kommunehelsetjenesten. Tidsskr Nor Legeforen 2008; 128: 1057-9. 